\title{
Responses of Bacterial Community in Cotton Rhizosphere Soil to the Application of Chitosan under Different Cultivation Patterns
}

\section{Wang jingang ( $\square$ 1274680853@qq.com )}

Shihezi University College of Agriculture https://orcid.org/0000-0002-9988-7187

Tian Tian

Shihezi University College of Agriculture

\section{Haijiang Wang}

Shihezi University College of Agriculture

\section{Zheng Liu}

Shihezi University College of Agriculture

jing Cui

Shihezi University College of Agriculture

\section{Xiaoyan Shi}

Shihezi University College of Agriculture

Jianghui Song

Shihezi University College of Agriculture

\section{Tianshen Li}

Shihezi University College of Agriculture

\section{Weidi Li}

Shihezi University College of Agriculture

\section{Mingtao Zhong}

Shihezi University College of Agriculture

\section{Research Article}

Keywords: Continuous cropping, Crop rotation, Chitosan, Root exudates, Bacterial diversity

Posted Date: September 23rd, 2021

DOI: https://doi.org/10.21203/rs.3.rs-844323/v1

License: (c) (1) This work is licensed under a Creative Commons Attribution 4.0 International License.

Read Full License 


\section{Abstract}

Aims Continuous cropping leads to the decreasing of soil nutrients and microbial diversity. This study aims to explore the effects of chitosan application on soil nutrient, enzyme activity, root exudates, and bacterial diversity in cotton field.

Methods Topsoils were collected from four treatments (continuous cotton cropping (Ct), continuous cotton cropping with chitosan application (CtC), rotation (Rt) (cotton-corn-wheat), and rotation with chitosan application (RtC)) to determine the effects of chitosan on soil nutrients, enzyme activity, root exudates, and bacterial diversity under different cultivation patterns. The structure and functions of bacterial communities were analyzed using Illumina MiSeq sequencing and PICRUSt approach.

Results Root exudates in CtC, Rt, and RtC treatments were higher than that in Ct treatment, while soil nutrients were lower. Soil enzyme activities were higher in Rt treatment than in Ct treatment, while only catalase activity was higher in $\mathrm{CtC}$ treatment. The abundance of Actinomycetes, Proteobacteria, Chloroflexi, and Bacteroidetes in Rt and CtC treatments, Firmicutes in Rt treatment, and Gemmatimonadetes in $\mathrm{CtC}$ treatment were higher than those in $\mathrm{Ct}$ treatment. PICRUSt analysis showed that the abundance of functional genes for soil microbial metabolism, environmental information processing, and organismal systems were higher in Rt, CtC, and RtC treatments than in $\mathrm{Ct}$ treatment, while that of genes for genetic information processing, cellular processes, and human diseases were slightly higher.

Conclusions Chitosan application in cotton fields under different cultivation patterns could improve nutrient availability in continuous-cropping soils by reducing root exudates and improving soil bacterial community diversity, to reduce continuous cropping obstacles.

\section{Introduction}

Xinjiang Province is the largest cotton production area in China and occupies an important position in agricultural production. Driven by the unique light and heat resources and high economic benefits of cotton, continuous cotton cropping is very common in Xinjiang Province (Lu et al. 2018). The long-term continuous cropping has led to the deterioration of soil fertility (Liu et al. 2005), the aggravation of cotton diseases and insect pests (Zhang et al. 2010), the reduction of yield and quality that restrict the sustainable and healthy development of the local cotton industry, which has been called as "continuous cropping obstacle" (Cao et al. 2016).

Continuous cropping obstacle is the result of the comprehensive action of "crop, soil, and microorganisms". It is closely related to soil microbial community structure, crop nutrient absorption, root allelochemicals metabolism, etc. (Zhang et al. 2010; Meng et al. 2012). Many studies have shown that the accumulation of root exudates in soil under long-term continuous cropping changes the root-zone soil environment, resulting in soil nutrient imbalance, decline of microbial diversity, and aggravation of crop diseases and pests (Xiao et al. 2012), which are directly related to the occurrence of soil diseases (Wu et 
al. 2019). Crop rotation could promote soil nutrient balance, improve soil physicochemical properties, and reduce the occurrence of continuous cropping obstacles (Asuming-Brempong et al. 2008; Qin et al. 2017). In addition, microbial diversity and community structure are affected by root exudates. Root exudates of different crops accumulate in the soil during rotations, which could enrich the nutrient source of soil microorganisms and promote the diversity of rhizosphere microbial community (Hu et al. 2018). Tan et al (2016) have found that crop rotation could improve soil physicochemical properties, enzyme activity, and a diversity of bacterial community in rhizosphere soil, reduce cotton root exudates ( $p$-Hydroxybenzoic acid, vanillin, and ferulic acid), and increase the abundance of some beneficial functional bacteria (actinomycetes, bacteroides, and planktomycetes). Li et al (2015) have found that long-term continuous cotton cropping could decrease soil enzyme activity and microbial diversity, while crop rotation could improve soil catalase and sucrase activities and microbial community structure diversity.

Reducing continuous cropping obstacles by using exogenous modifiers has been widely recognized and applied in agriculture at present (Mazzola et al. 2012; Jaiswal et al. 2014). Chitosan, a new irritant, could regulate crop growth for its good antibacterial properties against a variety of plant pathogens (Meng et al. 2010). The unique chelation, redox, and adsorption properties of chitosan could reduce the diffusion of root exudates into soil (Amborabé et al. 2008; Zakrzewska et al., 2005; Vaara 2008), and stimulate crop defense mechanism through inducing crop antibacterial activity. It has been found that chitosan could induce the increase of catalase activity to inhibit the growth of pathogens in soil, and play an important role in improving plant stress and disease resistance and regulating microbial diversity (Karthikeyan et al. 2005; Ma et al. 2005). In addition, chitosan could also activate available nutrients, increase the number of bacteria and the bacteria/fungi ratio, and maintain the ecological balance of soil microorganisms in continuous-cropping soils (Wang et al. 2016).

To explore the mechanism of chitosan application in reducing the continuous cropping obstacles in cotton fields under different cultivation patterns, the responses of cotton root exudates, rhizosphere soil nutrients, and enzyme activities in the soil $(0-20 \mathrm{~cm})$ under 20-year continuous cotton cropping and the soil under 20-year crop rotation (cotton, corn, and wheat) were analyzed, and the bacterial community structure and functional diversity in cotton rhizosphere soil were also determined based on Illumina miseq sequencing technology. We hypothesized that the application of chitosan might have a positive impact on the abundance of rhizosphere bacterial community that related to cotton growth under different cultivation patterns, This study could provide guidance for reducing the continuous cropping obstacles of cotton and promote the healthy development of cotton industry through scientific and reasonable measures.

\section{Materials And Methods}

The experiment was conducted at the Experimental Station of Agricultural College of Shihezi University, Shihezi City, Xinjiang Uygur Autonomous Region, China $\left(45^{\circ} 19^{\prime} \mathrm{N}, 86^{\circ} 3^{\prime} \mathrm{E}\right)$. This area (a.s.I. $428 \mathrm{~m}$ ) has a temperate continental climate, with an an annual sunshine duration of 2725-2820h, an active 
accumulated temperature $\geq 10{ }^{\circ} \mathrm{C}$ of $3595^{\circ} \mathrm{C} \sim 3729{ }^{\circ} \mathrm{C}$, an annual precipitation of $125.0 \sim 207.7 \mathrm{~mm}$, and a frost free period of $168 \sim 171$ days. The soil type is gray desert soil (Zhou et al. 2021).

Experimental design

The tested soils were obtained from a local long-term soil monitoring station. The topsoils $(0-20 \mathrm{~cm})$ were collected from a field under 20-year continuous cropping (cotton) and a field under 20-year crop rotation (cotton-corn-wheat) for pot experiment. The spacing between the two kinds of field was $100 \mathrm{~m}$, to ensure the comparability. The cotton variety used was Xinluzao 75.

Air-dried soil was sieved through a $2 \mathrm{~mm}$ mesh sieve and transferred into plastic pots. The diameter of the pot mouth was $20 \mathrm{~cm}$, the diameter of the pot bottom was $15 \mathrm{~cm}$, and the height was $20 \mathrm{~cm}$. About $5.5 \mathrm{~kg}$ soil was put into each pot. Four seeds were sown in each pot. When two true leaves appeared, two seedlings with uniform growth were retained. A total of four treatments were set up, including: continuous cropping (CT), continuous cropping with chitosan application (CTC), crop rotation (RT), and crop rotation with chitosan application (RTC). Each treatment had ten replicates.

Chitosan (molecular weight: $327 \mathrm{kDa}$, degree of deacetylation $\geq 95 \%$, viscosity: 100-200 mpa.s, N content: 4.8\%) was purchased from Macklin company, Shanghai, China. The concentration of chitosan for experiments was $0.1 \mathrm{~g} \cdot \mathrm{kg}^{-1}$ according to Cui et al (2015), Ma et al (2017), and the authors' previous test (Wang et al. 2021). Fertilization was consistent with the local practice (Liao et al. 2017). Urea (N: $46 \%)$ of $360 \mathrm{~kg} \cdot h a^{-1}$, heavy superphosphate $\left(\mathrm{P}_{2} \mathrm{O}_{5}: 46 \%\right)$ of $105 \mathrm{~kg} \cdot \mathrm{ha}^{-1}$, and potassium sulfate $\left(\mathrm{K}_{2} \mathrm{O}\right.$ : $50 \%$ ) of $75 \mathrm{~kg} \cdot \mathrm{ha}^{-1}$ were applied. All phosphorus and potassium fertilizer were basally applied through mixing with the soils before sowing. Forty percent of nitrogen fertilizer was basally applied, and $60 \%$ was applied with irrigation water and chitosan during cotton growth. A total of $0.55 \mathrm{~g}$ chitosan $(1 \mathrm{~L}$ chitosan solution) was applied with water for each pot in the whole growth period, and $10 \%, 10 \%, 20 \%, 30 \%, 20 \%$, and $10 \%$ were applied at the emergence stage, seedling stage, bud stage, initial flowering stage, full flowering stage, and boll-forming stage of cotton, respectively. The cotton was drip irrigated for six times in the whole growth period, to maintain the field water capacity at $70 \% \sim 80 \%$.

Collection of soil samples

Soil samples were collected when cotton was harvested in October 2020. Ten plants with uniform growth were selected from each treatment, and the roots were obtained. After that, the large soil and attached soil were removed first, and the soil on the root hair was brushed to obtain the rhizosphere soil. The ten rhizosphere soil was mixed as the rhizosphere soil of the treatment. Rhizosphere soils were put into sterile self sealing bags, stored in ice box, and taken back to the laboratory. One part was stored in - 80 ${ }^{\circ} \mathrm{C}$ refrigerator for subsequent determination of soil enzyme activity, root secretes, and microbial bacterial community, and the other part was dried naturally for determination of soil physical and chemical properties.

Determination items and methods 
The PHS-P acidity meter (Leici, Shanghai, China) was used to determine rhizosphere soil pH, the BPH6600 conductivity meter (Bell, Dalian, China) was used to determine rhizosphere soil conductivity, and the K9840-automatic Kjeldahl nitrogen analyzer (Qianjun, Shanghai, China) was used to determine the total nitrogen content in rhizosphere soil. Potassium dichromate oxidation-volume method was used for the determination of organic matter in rhizosphere soil, sodium bicarbonate extraction-molybdenum antimony colorimetric method was used for the determination of available phosphorus in rhizosphere soil, and atomic luminescence spectrophotometer method with ammonium acetate extraction was used for the determination of available potassium in rhizosphere soil (Bao 2000).

Determination of enzyme activity in rhizosphere soil

3,5-Dinitrosalicylic acid was used for colorimetric estimation to determine sucrase activity, indole phenol colorimetry was used to determine urease activity, diphenyl disodium phosphate spectrophotometry was used to determine alkaline phosphatase activity, volumetric method to determine catalase activity, and Gallas River method to determine protease activity (Lu, 2000).

Determination of root exudates

High performance liquid chromatography (HPLC) method was used to detect p-Hydroxybenzoic acid, vanillin, and ferulic acid in rhizosphere soil, which are closely related to the allelopathy of cotton. Fresh soil $(20 \mathrm{~g})$ was transferred in a centrifuge tube, followed by the addition of $25 \mathrm{~mL}$ of $2 \mathrm{~mol} \cdot \mathrm{L}^{-1}$ sodium hydroxide solution and mixing. After shaking for 24 hours, the mixture was centrifuged and filtered. The supernatant was acidified with $5 \mathrm{~mol} \cdot \mathrm{L}^{-1}$ hydrochloric acid to a $\mathrm{pH}$ of 2.5 , and humic acid was removed by centrifugation two hours after. Then, the supernatant was extracted 5 times with ethyl acetate. The extract was collected and evaporated to dryness under reduced pressure at $40{ }^{\circ} \mathrm{C}$. The residue was dissolved in $2 \mathrm{~mL}$ of $80 \%$ chromatographic methanol for HPLC determination. The result was converted according to the weight of the dried soil. High pressure liquid chromatograph (2695, Waters, US) was used for the determination. The mobile phase was a mixture of $1 \%$ phosphoric acid aqueous solution and methanol, the flow rate was $1 \mathrm{~mL} \cdot \mathrm{min}^{-1}$, the wavelength selected was $280 \mathrm{~nm}$, and the column temperature was $25^{\circ} \mathrm{C}$. The sample were qualitatively determined by the retention time of the standard chromatogram, and the peak area was used for quantitative analysis (Zhou et al. 2012; Yi et al. 2020).

Analysis of bacterial community composition in rhizosphere soil

E.Z.N.A.DNA kit (Omega Bio-tek, Norcross, GA, U.S.A) was used to extract microbial DNA from rhizosphere soil samples. According to the instructions of the manufacturer, two primers of $338 \mathrm{~F}$ (5'ACTCCTACGGGAGGCAGCAG-3') and 806R (5'- GGACTACHVGGGTWTCTAAT-3') were used for PCR amplification. The V3 region of bacterial $16 \mathrm{~S}$ ribosomal RNA gene in the DNA was obtained by PCR amplification. The PCR reaction was made in triplicate at $95^{\circ} \mathrm{C}$ for $3 \mathrm{~min}$, in a mixture at a total volume of $20 \mu \mathrm{L}$ containing $4 \mu \mathrm{L}$ 5×Fast Pfu Buffer, $2 \mu \mathrm{L} 2.5$ mM dNTPs, $0.4 \mu \mathrm{L}$ Fast Pfu polymerase, and $10 \mathrm{ng}$ 
template DNA. Then it was circulated 27 times under the conditions of $95^{\circ} \mathrm{C}$ for $30 \mathrm{~s}, 55^{\circ} \mathrm{C}$ for $30 \mathrm{~s}$, and $72{ }^{\circ} \mathrm{C}$ for $45 \mathrm{~s}$, and finally extended for $10 \mathrm{~min}$ at $72{ }^{\circ} \mathrm{C}$. The PCR products were electrophoretic in $1 \%$ agarose gel and purified by AxyPrep DNA Gel Extraction Kit (Axygen Biosciences, Union City, CA, U.S.A) according to the manufacturer's instructions. QuantiFluor ${ }^{\mathrm{TM}}$-ST (Promega, USA) was used for quantification, miseq sequencing, and data analysis (Majorbio, Shanghai, China)

Data processing

SPSS Amos 21.0 (Amos IBM, USA), Excel 2016 (Microsoft, USA), and Origin 2018 (Origin Lab, Massachusetts, USA) software were used to analyze and process the data, and the LSD method was used to determine the significant difference at $P<0.05$.

\section{Results}

Effects of chitosan application on physicochemical properties of cotton rhizosphere soil under different cultivation patterns

Cultivation patterns and chitosan application all had effects on the $\mathrm{pH}$, electrical conductivity, and the content of organic matter, total nitrogen, alkali hydrolyzable nitrogen, available potassium, and available phosphorus in rhizosphere soil (Table 1). The nutrient content of rhizosphere soil in the Rt treatment was higher than that in the $\mathrm{Ct}$ treatment. The $\mathrm{pH}$ and the content of organic matter, total nitrogen, alkali hydrolyzable nitrogen, available potassium, and available phosphorus of rhizosphere soil in the Rt treatment were $5.53 \%, 13.22 \%, 36.59 \%, 5.45 \%, 17.22 \%$, and $7.99 \%$ higher than those in the $\mathrm{Ct}$ treatment, respectively $(P<0.05)$, while the EC was lower $(P>0.05)$. The application of chitosan obviously increased the nutrient content in the $\mathrm{Ct}$ treatment. The $\mathrm{pH}$ and the content of organic matter, total nitrogen, alkali hydrolyzable nitrogen, available potassium, and available phosphorus in the CtC treatment were $10.40 \%$, $6.41 \%, 13.75 \%, 2.77 \%, 7.09 \%$, and $4.03 \%$ higher than those in the Ct treatment, respectively $(P<0.05)$, while there were insignificant increases in the Rt treatment $(P>0.05)$. 
Table 1

Soil physicochemical properties in different treatments

\begin{tabular}{|c|c|c|c|c|c|c|c|}
\hline Treatment & $\mathrm{pH}$ & $\begin{array}{l}\text { Conductivity } \\
\left(\mu \mathrm{s} \cdot \mathrm{cm}^{-1}\right)\end{array}$ & $\begin{array}{l}\text { Organic } \\
\text { matter } \\
\left(\mathrm{g} \cdot \mathrm{kg}^{-1}\right)\end{array}$ & $\begin{array}{l}\text { Total } \\
\text { nitrogen } \\
\left(\mathbf{g} \cdot \mathrm{kg}^{-1}\right)\end{array}$ & $\begin{array}{l}\text { Nitrate } \\
\text { nitrogen } \\
\left(\mathrm{mg} \cdot \mathrm{kg}^{-}\right. \\
\left.{ }^{1}\right)\end{array}$ & $\begin{array}{l}\text { potassium } \\
\left(\mathrm{mg} \cdot \mathrm{kg}^{-1}\right)\end{array}$ & $\begin{array}{l}\begin{array}{l}\text { Available } \\
\text { phosphorus }\end{array} \\
\left(\mathrm{mg} \cdot \mathrm{kg}^{-1}\right)\end{array}$ \\
\hline $\mathrm{Ct}$ & $\begin{array}{l}7.02 \pm \\
0.34 b\end{array}$ & $\begin{array}{l}318 \pm \\
15.90 \mathrm{a}\end{array}$ & $\begin{array}{l}17.72 \pm \\
0.61 \mathrm{c}\end{array}$ & $\begin{array}{l}0.80 \pm \\
0.07 \mathrm{c}\end{array}$ & $\begin{array}{l}37.20 \pm \\
0.04 \mathrm{c}\end{array}$ & $\begin{array}{l}152.52 \pm \\
7.63 c\end{array}$ & $\begin{array}{l}28.03 \pm \\
0.80 \mathrm{~b}\end{array}$ \\
\hline $\mathrm{CtC}$ & $\begin{array}{l}7.75 \pm \\
0.38 a\end{array}$ & $\begin{array}{l}310 \pm \\
15.50 \mathrm{a}\end{array}$ & $\begin{array}{l}19.19 \pm \\
0.68 \mathrm{~b}\end{array}$ & $\begin{array}{l}0.89 \pm \\
0.08 \mathrm{~b}\end{array}$ & $\begin{array}{l}39.26 \pm \\
0.04 \mathrm{~b}\end{array}$ & $\begin{array}{l}161.34 \pm \\
8.17 b\end{array}$ & $\begin{array}{l}29.16 \pm \\
0.81 a\end{array}$ \\
\hline Rt & $\begin{array}{l}7.83 \pm \\
0.39 a\end{array}$ & $\begin{array}{l}306 \pm \\
15.33 a\end{array}$ & $\begin{array}{l}21.79 \pm \\
0.74 a\end{array}$ & $\begin{array}{l}1.12 \pm \\
0.08 \mathrm{a}\end{array}$ & $\begin{array}{l}41.28 \pm \\
0.04 a\end{array}$ & $\begin{array}{l}180.78 \pm \\
8.89 a\end{array}$ & $\begin{array}{l}30.27 \pm \\
0.81 \mathrm{a}\end{array}$ \\
\hline RtC & $\begin{array}{l}7.86 \pm \\
0.39 a\end{array}$ & $\begin{array}{l}309 \pm \\
15.45 a\end{array}$ & $\begin{array}{l}22.77 \pm \\
0.71 \mathrm{a}\end{array}$ & $\begin{array}{l}1.17 \pm \\
0.08 a\end{array}$ & $\begin{array}{l}41.29 \pm \\
0.04 a\end{array}$ & $\begin{array}{l}181.17 \pm \\
9.06 a\end{array}$ & $\begin{array}{l}31.43 \pm \\
0.82 a\end{array}$ \\
\hline
\end{tabular}

Effects of chitosan application on enzyme activities in cotton rhizosphere soil under different cultivation patterns

Cultivation patterns and chitosan application had effects on enzyme activities in rhizosphere soil (Table 2). The activities of phosphatase, urease, sucrase, catalase and protease in rhizosphere soil in the Rt treatment were $14.80 \%, 51.75 \%, 52.73 \%, 64.25 \%$, and $49.90 \%$ higher than those in the Ct treatment, respectively $(P<0.05)$. The activities of catalase in the $\mathrm{CtC}$ treatment was $38.34 \%$ higher than that in the Ct treatment $(P<0.05)$, while there was no difference in the activities of phosphatase, urease, sucrase, and protease $(P>0.05)$. The nutrient content of rhizosphere soil in the Rt treatment did not show a significant increase $(P>0.05)$.

Table 2

Enzyme activities in rhizosphere soil in different treatments

\begin{tabular}{|c|c|c|c|c|c|}
\hline Treatment & $\begin{array}{l}\text { Phosphatase } \\
\mu \mathrm{mol} \cdot(\mathrm{g} \cdot \mathrm{h})^{-1}\end{array}$ & $\begin{array}{l}\text { Urease } \\
\mu \mathrm{g} \cdot(\mathbf{g} \cdot \mathbf{h})^{-1}\end{array}$ & $\begin{array}{l}\text { Sucrase } \\
\mathrm{mg} \cdot(\mathrm{g} \cdot \mathrm{h})^{-1}\end{array}$ & $\begin{array}{l}\text { Catalase } \\
\mathrm{mL} \cdot(\mathrm{g} \cdot 20 \mathrm{~min})^{-1}\end{array}$ & $\begin{array}{l}\text { Proteinase } \\
\mu \mathbf{g} \cdot(\mathbf{g} \cdot h)^{-1}\end{array}$ \\
\hline $\mathrm{Ct}$ & $1.96 \pm 0.09 b$ & $1.14 \pm 0.06 b$ & $6.41 \pm 0.32 b$ & $1.93 \pm 0.10 d$ & $5.11 \pm 0.26 b$ \\
\hline $\mathrm{CtC}$ & $2.01 \pm 0.09 b$ & $1.16 \pm 0.07 b$ & $6.66 \pm 0.33 b$ & $2.67 \pm 0.13 c$ & $5.32 \pm 0.28 b$ \\
\hline Rt & $2.25 \pm 0.11 a$ & $1.73 \pm 0.09 a$ & $9.79 \pm 0.49 a$ & $3.17 \pm 0.16 a b$ & $7.66 \pm 0.38 a$ \\
\hline RtC & $2.34 \pm 0.12 a$ & $1.83 \pm 0.09 a$ & $10.09 \pm 0.52 a$ & $3.21 \pm 0.18 a$ & $7.69 \pm 0.38 a$ \\
\hline
\end{tabular}


Effects of chitosan application on root exudates in cotton rhizosphere soil under different cultivation patterns

Cultivation patterns and chitosan application had effects on the content of cotton root exudates in rhizosphere soil. The content of cotton root exudates in the Rt and CtC treatments were lower than that in the Ct treatment (Fig. 1). The contents of hydroxybenzoic acid, vanillin, and ferulic acid in the Rt treatment were $32.31 \%, 47.93 \%$, and $67.86 \%$ lower than those in the Ct treatment, respectively $(P<0.05)$. The content of cotton root exudates in the $\mathrm{CtC}$ treatment were lower than those in the $\mathrm{Ct}$ treatment. The contents of hydroxybenzoic acid, vanillin, and ferulic acid in the CtC treatment were $12.41 \%, 23.69 \%$, and $36.98 \%$ lower than those in the $\mathrm{Ct}$ treatment, respectively $(P<0.05)$. The content of cotton root exudates in rhizosphere soil in the Rt treatment did not show a significant increase $(P>0.05)$. The response index (RI) values in the $\mathrm{CtC}$, Rt, and RtC treatments were negative, indicating that rotation and application of chitosan could obviously inhibit the production of root exudates $(P<0.05)$.

Effects of chitosan application on bacterial community in cotton rhizosphere soil under different cultivation patterns

Effects of chitosan application on the number of OTUs in cotton rhizosphere soil under different cultivation patterns

All sequences were clustered into operational taxonomic units (OTUs) taking $97 \%$ as the threshold, and a total of 3678 OTUs were generated for the four treatments (Fig. 2). There were 1617 common OTUs for the treatments, accounting for $43.96 \%$ of all OTUs. Between Ct and Rt treatment, the number of unique OTUs in the Ct treatment was 754, and that in the Rt treatment was 507. Between $\mathrm{Ct}$ and $\mathrm{CtC}$ treatment, the number of unique OTUs in the Ct treatment was 669 , and that in the CtC treatment was 523. Between Rt and RtC treatment, the number of unique OTUs in the Rt treatment was 509, and that in the RtC treatment was 639 . Therefore, crop rotation decreased the number of unique OTUs in the bacteria in cotton rhizosphere soil compared with $\mathrm{Ct}$ treatment, and the application of chitosan under the cultivation pattern of $\mathrm{Ct}$ also decreased the number of unique OTUs. Compared with rotation, chitosan application under the cultivation pattern of Rt increased the number of unique OTUs in the bacteria in cotton rhizosphere soil.

Effects of chitosan application on the diversity and richness of soil bacteria in cotton rhizosphere soil under different cultivation patterns

The a diversity was determined to analyze the effects of application of chitosan on the diversity and richness of rhizosphere soil bacteria under different cultivation patterns (Table 3). The indexes reflecting species diversity showed that the Shannon index in the Rt and CtC treatments were lower than that in the Ct treatment, and there was no difference in Simpson index. The Shannon index in the RtC treatment was higher than that in the Rt treatment, and there was no difference in Simpson index. The indexes reflecting species richness showed that the ACE and Chao1 indexes in the Rt and CtC treatments were lower than those in the Ct treatment, and the coverage index in the RtC treatment was slightly higher than that in the 
Rt treatment. Compared with Ct treatment, CtC and Rt decreased the bacterial richness and species number in rhizosphere soil, while RtC increased the bacterial richness and species number in rhizosphere soil.

Table 3

Diversity indexes of rhizosphere soil bacteria in different treatments

\begin{tabular}{|llllll|}
\hline \multicolumn{5}{|c|}{ Diversity index } & \multicolumn{5}{l|}{ Richness index } \\
\hline Treatment & Shannon & Simpson & Ace & Chao & Coverage \\
\hline Ct & $6.662 \pm$ & $0.003 \pm$ & $3220.811 \pm$ & $3196.547 \pm$ & $0.988 \pm$ \\
& $0.33 a$ & $0.00 \mathrm{a}$ & $161.04 \mathrm{a}$ & $159.83 \mathrm{a}$ & $0.05 \mathrm{a}$ \\
$\mathrm{CtC}$ & $6.544 \pm$ & $0.003 \pm$ & $3127.506 \pm$ & $3166.403 \pm$ & $0.990 \pm$ \\
& $0.32 \mathrm{a}$ & $0.00 \mathrm{a}$ & $156.38 \mathrm{a}$ & $158.32 \mathrm{a}$ & $0.05 \mathrm{a}$ \\
$\mathrm{Rt}$ & $6.241 \pm$ & $0.003 \pm$ & $2990.431 \pm$ & $3014.315 \pm$ & $0.989 \pm$ \\
& $0.31 \mathrm{a}$ & $0.00 \mathrm{a}$ & $149.52 \mathrm{a}$ & $150.72 \mathrm{a}$ & $0.05 \mathrm{a}$ \\
\hline RtC & $6.580 \pm$ & $0.003 \pm$ & $3162.953 \pm$ & $3218.018 \pm$ & $0.988 \pm$ \\
& $0.32 \mathrm{a}$ & $0.00 \mathrm{a}$ & $158.15 \mathrm{a}$ & $160.90 \mathrm{a}$ & $0.05 \mathrm{a}$ \\
\hline \multicolumn{2}{|l}{ Different lowercase letters in the same column indicate the significant difference among different } \\
treatments $(P<0.05)$ & & & & \\
\hline
\end{tabular}

Effects of chitosan application on the bacterial community structure in cotton rhizosphere soil under different cultivation patterns

Twelve bacterial phyla with relative abundance greater than $1 \%$ were detected in rhizosphere soil (Fig. 3). The dominant flora with relative abundance greater than $10 \%$ for the four treatments were Actinobacteria $(16.92 \%-26.71 \%)$, Proteobacteria $(20.56 \%-23.57 \%)$, and Chloroflexi $(14.16 \%-17.32 \%)$. The relative abundance of Actinomycetes, Proteobacteria, Chloroflexi, Firmicutes, and Bacteroidetes in rhizosphere soil in the Rt treatment were $42.01 \%, 0.92 \%, 13.49 \%, 34.87 \%$, and $12.03 \%$ higher than those in the $\mathrm{Ct}$ treatment, respectively, while that of Acidobacteria and Gemmatimonadetes were $51.07 \%$ and $33.80 \%$ lower than those in the $\mathrm{Ct}$ treatment, respectively. The relative abundance of Actinobacteria, Proteobacteria, Chloroflexi, Gemmatimonadetes, and Bacteroidea in the CtC treatment were $31.36 \%$, $7.05 \%, 22.32 \%, 9.52 \%$, and $5.69 \%$ higher than those in the Ct treatment, respectively, while that of Acidobacteria, Firmicutes, and Planctomycetes were $24.02 \%, 59.02 \%$, and $46.03 \%$ lower than those in the $\mathrm{Ct}$ treatment, respectively. The relative abundance of Choroflexi and Planctomycetes in the RtC treatment were lower than those in the Rt treatment. Therefore, the effects of chitosan application on the relative abundance of dominant bacteria in rhizosphere soil were different that of cultivation patterns.

RDA analysis of bacterial community and environmental factors in rhizosphere soil

The RDA analysis showed that the contribution rate of the first sequence was $92.50 \%$, and that of the second sequence was $6.40 \%$. The cumulative contribution rate was $98.90 \%$. Therefore, it could explain 
the relationships between soil bacterial community and soil environmental factors (Fig. 4). The dominant bacterial communities respond differently to the soil physicochemical properties. Actinomycetes and Choroflexi with a high relative abundance were positively correlated with soil $\mathrm{pH}$. Proteobacteria, Bacteroides, and Gemmatimonadetes were positively correlated with soil enzymes, organic carbon, total nitrogen, and available potassium. Acidobacteria and Verrucomicrobia were positively correlated with cotton root exudates in rhizosphere soil. Unclassified bacteria were positively correlated with soil EC. Firmicutes, Cyanophyta, and Nitrospirae had little correlation with environmental factors. Further study showed that the bacterial community composition of different treatments was correlated with environmental factors. The bacterial community composition in the Ct treatment was positively correlated with root exudates and EC, and negatively correlated with soil physicochemical properties except EC and soil enzyme activity. The bacterial community composition in the Rt, CtC, and RtC treatments were negatively correlated with the content of root exudates. Among them, RtC had a greater effect on soil nutrient content, while Rt and CtC had a greater effect on soil enzyme activity.

Prediction of bacterial PICRUSt function in rhizosphere soil

To make clear the effects of chitosan application on the metabolic function of bacteria in rhizosphere soil under different cultivation patterns, PICRUSt software was used to predict the functions (Fig. 5). The predicted functional gene families were annotated into KEGG database, it was found that the functions of gene sequences of all flora with relative abundance $>1 \%$ in primary metabolic pathways annotated could be divided into six categories: metabolism, environmental information processing, genetic information processing, cellular processes, human diseases, and organismal systems, in which metabolism is the most important function of rhizosphere soil bacteria, accounting for $60.60 \%-62.75 \%$. The abundance of functional genes of metabolism, environmental information processing, and organismal systems in the $\mathrm{Rt}, \mathrm{CtC}$, and RtC treatments were higher than those in the $\mathrm{Ct}$ treatment $(P<0.05)$, while that of functional genes of cellular processes, genetic information processing, and human diseases showed an insignificant increasing trend $(P>0.05)$.

According to the prediction of secondary functions (Fig. 6), there were 40 subfunctions for the genes of rhizosphere soil bacteria for the four treatments, such as carbohydrate metabolism, amino acid metabolism, membrane transport, signal transduction, and cofactor and vitamin metabolism among which carbohydrate metabolism (13.09\% 13.27\%), amino acid metabolism (12.51\% 12.76\%), and membrane transport $(12.04 \% \sim 12.64 \%)$ were the main subfunctions. The abundance of genes of cofactor and vitamin metabolism, nucleotide metabolism, folding, classification and degradation, bacteria-related infectious diseases, immune system, signal molecules, and interaction in the Rt treatment decreased obviously $(P<0.05)$, while that of genes of carbohydrate metabolism, degradation and metabolism of exogenous substances, metabolism of terpenoids and ketones, endocrine system, nervous system and substance-dependent genes increased obviously $(P<0.05)$, compared with those in the Ct treatment. The abundance of functional genes of carbohydrate metabolism, amino acid metabolism, lipid metabolism, degradation and metabolism of exogenous substances in the CtC treatment increased obviously $(P<0.05)$, while the abundance of functional genes of energy metabolism, cofactor and 
vitamin metabolism, nucleotide metabolism, translation, replication, and repair decreased obviously $(P<$ 0.05), compared with those in the $\mathrm{Ct}$ treatment. However, there was no difference in the subfunctions among functional genes $(P>0.05)$.

\section{Discussion}

In recent years, many studies have confirmed that cultivation patterns could effectively control the occurrence of continuous cropping obstacles to a certain extent, and reasonable rotation could improve soil physicochemical properties and nutrient balance (Asuming-Brempong et al. 2008; Qin et al. 2017). In this study, the content of root cotton exudates (hydroxybenzoic acid, vanillin, and ferulic acid) in rhizosphere soil under crop rotation decreased, and the $\mathrm{pH}$ value and the content of nutrients (organic matter, total nitrogen, alkali hydrolyzable nitrogen, available potassium, and available phosphorus) of rhizosphere soil increased, compared with those in the continuous-cropping soil. This may be due to that the allelochemicals released from different crop in the rotation of cotton, corn, and wheat could produce antagonistic effects (Fig. 7) (Zhuang et al. 2009). Besides, the reduced hydroxybenzoic acid, vanillin, and ferulic acid could reduce the damage of toxic substances, improve the content of soil available nutrients to a certain extent, and accelerate the release of alkali hydrolyzable nitrogen, available potassium, and available phosphorus (Sun et al. 2019). As one of the important parameters for evaluating soil nutrients, soil enzymes participate in the fixation and release of soil nutrients and various redox reactions (Bending et al. 2002). In this study, the enzyme activities (phosphatase, urease, sucrase, catalase and protease) in rhizosphere soil in the continuous-cropping soil were lower than those in the soil under crop rotation, indicating that the high plant diversity in crop rotation could increase soil microbial diversity and soil enzyme activities (Niu et al. 2018).

Crop rotation could change the rhizosphere soil microbial community structure and regulate crop population composition and ontogeny through rhizosphere soil microbial feedback (Bakker et al., 2012; Olanrewajuet al. 2019). In this study, the bacterial community diversity (Shannon and Simpson indexes) in the soil under crop rotation increased, while the richness (Chao1, Ace, and Coverage index) decreased, compared with those in the continuous cropping soil, which may be caused by the decrease in the proportion of dominant bacteria phyla. The increases of acid bacteria, nitrospira and other bacteria in continuous cropping soil is mainly related to the large use of nitrogen fertilizer in local cotton planting (Hong et al. 2019). Crop rotation also promoted the enrichment of Actinomycetes, Bacteroidetes, Proteobacteria, Planctomycetes, Chloroflexi, and Verrucomicrobia in cotton rhizosphere soil. Study has shown that Verrucomicrobia could decompose organic matter to improve the stress resistance of plants (Banerjee et al. 2016). Planctomycetes plays an important role in the nutrient absorption of plants, especially the utilization of carbon and nitrogen sources (Bhattacharyya et al., 2017). In addition, crop rotation increased the number of some functional bacteria, such as Planctomyces, Gemmata, Flavisolibacter, Luteolibacter, etc. This is similar to the research results of Edward et al (2015) on rice, Niu et al (2017) on corn, and Zhang et al (2021) on wheat. It indicates that crop rotation could provide a suitable living environment for beneficial bacteria in cotton rhizosphere soil through the changing of crops (Coskun et al. 2017). Therefore, crop rotation could bring the change of the bacterial flora, which 
has a positive effect on the growth of cotton. The redundancy analysis of rhizosphere soil bacterial community, nutrients, enzyme activities, and root exudates showed that soil nutrients and enzyme activities were positively correlated with most bacterial genera and negatively correlated with only a few bacterial genera. Rhizosphere soil with excellent physicochemical properties could provide suitable living environment, sufficient food sources, and environmental gradients for microorganisms, which promotes microbial growth and reproduction and the diversity of soil microorganisms (Yu et al. 2011). Root exudates were negatively correlated with most bacteria and positively correlated with acid bacteria such as Acidobacteria, indicating that long-term continuous cotton cropping promoted the accumulation of root exudates and the reproduction of pathogenic bacteria, while reduced the diversity of beneficial bacteria, leading to the transformation of soil microbial community in cotton rhizosphere from bacterial type to fungal type (Liu et al. 2009). However, it may be toxic to the growth of cotton.

Previous study has shown that adding exogenous modifiers could alleviate continuous cropping obstacles (Jaiswal et al. 2014). Relevant reports have confirmed that chitosan could not only improve the stress resistance of crops, the reproduction of beneficial microorganisms, and soil environment, but also inhibit the growth of a variety of bacterial pathogens (Amborabé et al. 2008; Zakrzewska et al. 2005). In this study, the application of chitosan in the continuous cropping soil obviously reduced the content of root exudates and improved the nutrient status of cotton rhizosphere soil, but the effect on soil enzymes did not show a similar law. Except catalase, the effects on other enzymes were not obvious, which might be due to that the interaction between positively charged chitosan molecules and negatively charged pathogen surfaces destroyed cell structure and caused damage to pathogens (Fig. 7). Catalase plays an important role in this pathway (Meng et al. 2010), which could explain why the catalase activity, playing a role in the defense of crops against pathogens, increased in the CtC treatment in this study. The application of chitosan could improve the diversity, evenness, and richness of bacteria in continuous cropping soil, promote the accumulation of beneficial bacteria such as Actinomycetes, Bacteroidetes, Proteobacteria, Planctomycetes, and Chloroflexi, and inhibit the reproduction of Acidobacteria and Firmicutes. Therefore, chitosan could improve antibacterial capacity against plant pathogens through changing the structure of soil bacterial community, increase the number and activity of soil enzymes mainly produced by soil microorganisms, and improve the soil enzyme system. It may be a reason for chitosan in alleviating the continuous cropping obstacles (Meng et al. 2009).

PICRUSt analysis linked microbial changes and biological functions through annotating into KEGG database (Sun et al. 2006). This study found that the genes of rhizosphere soil bacteria of the four treatments had 40 subfunctions, such as carbohydrate metabolism, amino acid metabolism, membrane transport, signal transduction, cofactor and vitamin metabolism, and so on, indicating that the functions are very rich. Among them, metabolism $(60.60 \%-62.75 \%)$ was the main function of the functional genes that maintains the survival of bacteria by ingesting carbohydrates, amino acids, energy, and vitamins, which was consistent with the results of Du et al (2019) and Yang et al (2020). It was found that the metabolic function of rhizosphere soil in the Rt, $\mathrm{CtC}$, and RtC treatments were higher than that in the $\mathrm{Ct}$ treatment, which was mainly reflected in carbohydrate metabolism, degradation and metabolism of exogenous substances, and metabolism of terpenoids and polyketones. This is related to the content of 
soil beneficial bacteria. Soil microorganisms promote crop growth and increase yield through metabolic activities. The relative abundance of Firmicutes and Bacteroides in the Rt and CtC treatments were higher than those in the Ct treatment, which was due to that Proteobacteria, Gemmatimonadetes, and Planctomycetes could antagonize plant pathogens through metabolism to produce antibiotics or plant auxins, and promote crop growth (Berendsen et al. 2012; Lakshmanan et al. 2014; Song et al. 2014). Under crop rotation, the nutrient source for soil microorganisms in the rhizosphere increases, and the $\mathrm{C}$ and $\mathrm{N}$ continue to improve with the increase of microorganisms (Wen et al. 2016), which promote the metabolism of carbohydrates, exogenous substances, terpenoids, and polyketones, and improve the abundance of functional genes. Moreover, it was found that carbohydrate metabolism, amino acid metabolism, and membrane transport accounted for a high proportion in the secondary functional layer related to metabolism. Carbohydrates produced during photosynthesis are consumed by other organisms, which regulates the metabolic formation, decomposition, and mutual transformation of carbohydrates in organisms (Sun et al. 2020). Amino acid metabolism decomposes amino acid into aKetoacids, amines, and carbon dioxide through deamination, transamination, combined deamination, and decarboxylation. Amino acid metabolism is closely related to plant nitrogen cycle (Yang et al. 2020). However, this study found that the application of chitosan had no effect on the functional bacteria in rhizosphere soil under crop rotation. The specific mechanism needs to be further explored.

\section{Conclusion}

Long-term continuous cotton cropping led to the imbalance of soil microbial community structure and the decline of soil quality, while crop rotation and application of chitosan could reduce the content of root exudates, improve rhizosphere soil nutrients, enzyme activities, and the relative abundance of dominant flora, and reduce the diversity of harmful bacteria. In addition, crop rotation and application of chitosan could increase the relative abundance of functional genes of metabolism, organismal systems, and environmental information processing in soil microorganisms $(P<0.05)$, and the relative abundance of functional genes of cellular processes, genetic information processing, and human diseases had an inapparent increase $(P>0.05)$. Therefore, the application of chitosan could be used as a technical means to effectively reduce the continuous cropping obstacles of cotton under different cultivation patterns, and improve the utilization cycle of soil resources. However, the mechanism still needs to be further studied. Soil microbial communities include bacteria, fungi, and actinomycetes, which are closely related to each other. In the further experiment, we will continue to explore the relationship between environmental factors and rhizosphere soil fungi and bacteria, to systematically predict microbial functions and understand the distribution law of microorganisms.

\section{Declarations}

\section{Acknowledgments}

This work is supported by the International Science and Technology Cooperation Project (2015DFA11660), the Corps Science and Technology Project (2018AA004, 2018AA005, and 2020AB018), 
and the Shihezi University Project (RCZX201425 and RCZK20208).

\section{Compliance with ethical standards}

Conflict of interest The authors declare that they have no conflicts of interest.

\section{References}

Amborabé B-E, Bonmort J, Fleurat-Lessard P, Roblin G (2008) Earlyevents induced by chitosan on plant cells. J Exp Bot 59(9):2317-2324. https://doi.org/10.1093/jxb/ern096

Asuming-Brempong S, Gantner S, Adiku SGK, Archer G, Edusei V, Tiedje JM (2008) Changes in the biodiversity of microbial populations in tropical soils under different fallow treatments. Soil Biol Biochem 40(11):2811-2818. https://doi.org/10.1016/j.soilbio.2008.08.010

Bakker MG, Manter DK, Sherlin AM, Weir TL, Vivanco JM (2012) Harnessing the rhizosphere microbiome through plant breeding and agricultural management. Plant Soil 360(1-2):1-13.

https://doi.org/10.1007/s11104-012-1361-x

Banerjee S, Kirkby CA, Schmutter D, Bissett A, Kirkegaard JA, Richardson AE (2016) Network analysis reveals functional redundancy and keystone taxa amongst bacterial and fungal communities during organicmatter decomposition in an arable soil. Soil Biol Biochem 97:188-198.

https://doi.org/10.1016/j.soilbio.2016.03.017

Bao SD (2000) Soil and Agricultural Chemistry Analysis, 3rd edn. China Agriculture Press, Beijing

Bending GD, Turner MK, Jones JE (2002) Interactions between crop residue and soil organic atter quality and the functional diversity of soil microbial communities. Soil Biol Biochem 34(8):1073-1082. https://doi.org/10.1016/S0038-0717(02)00040-8

Berendsen RL, Pieterse CMJ, Bakker PAHM (2012) The rhizosphere microbiome and plant health. Trends Plant Sci 17(8):478-486. https://doi.org/10.1016/j.tplants.2012.04.001

Bhattacharyya P, Roy KS, Nayak AK, Shahid M, Lal B, Gautam P, Mohapatra T (2017) Metagenomic assessment of methane production -oxidation and nitrogen metabolism of long term manured systems in lowland rice paddy. Sci Total Environ 586:1245-1253. https://doi.org/10.1016/j.scitotenv.2017.02.120

Cao JJ (2016) Effect of returning straw into field on the soil aggregates nutrients, organic carbon components. Shihezi University, Shihezi

Chen A, Gu L, Xu N, Feng FJ, Chen DX, Yang CY, Zhang B, Li MJ, Zhang ZY (2019) NB-LRRs not responding consecutively to Fusarium oxysporum proliferation caused replant disease formation of Rehmannia glutinosa. Int J Mol Sci 20(13):E3203. https://doi.org/10.3390/ijms20133203 
Coskun D, Britto DT, Shi W, Kronzucker HJ (2017) How plant root exudates shape the nitrogen cycle. Trends Plant Sci 22(8):661-673. https://doi.org/10.1016/j.tplants.2017.05.004

Du YJ, Gao GL, Chen LH, Ding GD, Zhang Y, Cao HY (2019) Soil bacteria community structure and function prediction in the Hulun Buir sandy area. China Environmental Science 39(11):4840-4848. https://doi.org/10.19674/j.cnki.issn1000-6923.2019.0564

Edwards J, Johnson C, Santos-Medellín C, Lurie E, Podishetty NK, Bhatnagar S, Eisen JA, Sundaresan V (2015) Structure, variation, and assembly of the root-associated microbiomes of rice. Proc Natl Acad Sci USA 112(8):E911-E920. https://doi.org/10.1073/pnas.1414592112

Hong J, Kang JY, Liu YQ, Gao XZ, Yi XX (2019) The effects of continuous lettuce and lettuce-spinach rotation on soil bacterial community structure. Biotechnology Bulletin 35(8): 17-26. https://doi.org/10.13560/j.cnki. biotech.bull.1985.2019-0182

Hu LF, Robert C, Cadot S, Zhang X, Ye M, Li BB, Manzo D, Noemie C, Thomas S Van dHMGA (2018) Root exudate metabolites drive plant-soil feedbacks on growth and defense by shaping the rhizosphere microbiota. Nat Commun 9(1):2738. https://doi.org/10.1038/s41467-018-05122-7

Jaiswal AK, Elad Y, Graber ER, Frenkel O (2014) Rhizoctonia solani suppression and plant growth promotion in cucumber as affected by biochar pyrolysis temperature, feedstock and concentration. Soil Biol Biochem 69:110-118. https://doi.org/10.1016/j.soilbio.2013.10.051

Karthikeyan M, Jayakumar V, Radhika K, Bhaskaran R, Velazhahan R, Alice D (2005) Induction of resistance in host against the infection of leaf blight pathogen (Alternaria palandui) in onion (Allium cepavar aggregatum). Indian J Biochem Biophys 42(6):371-377.

https://doi.org/10.1089/ham.2005.6.346

Lakshmanan V, Selvaraj G, Bais HP (2014) Functional soil microbiome: Belowground solutions to an aboveground problem. Plant Physiol 166(2):689-700. https://doi.org/10.1104/pp.114.245811

Liao N, Hou ZA, Li Q, Ru SB, Guo HJ (2015) Effects of biological carbon on cotton yield and nitrogen utilization efficiency under different nitrogen levels. Journal of Plant Nutrition Fertilizer 21(3):782-791. https://doi.org/10.11674/zwyf.2015.0326

Liu JG, Zhang W, Li YB, Sun YY, Bian XM (2009) Effects of long-term continuous cropping system of cotton on soil physical-chemical properties and activities of soil enzyme in oasis in Xinjiang. Scientia Agricultura Sinica 42(2):725-733. https://doi.org/10.3864/j.issn.0578-1752.2009.02.044

Liu XB, Liu JD, Xing BS, Herbert SJ, Meng K, Han XZ, Zhang XY (2005) Effects of long-term continuous cropping, tillage, and fertilization on soil organic carbon and nitrogen of black soils in China. Commun Soil Sci Plant Anal 36(9-10):1229-1239. https://doi.org/10.1081/CSS-200056917 
Lu RK (2000) The Analysis Method of Soil Agricultural Chemistry China Agricultural Sciences and Technology Press, Beijing

Lu XR, Jia XY, Niu JH (2018) The present situation and prospects of cotton industry development in China. Scientia Agricultura Sinica 51(1):26-36. https://doi.org/10.3864/j.issn.0578-1752.2018.01.003

Ma YY, Xu WL, Tang GM, Gu MY, Xue QH (2017) Effect of cotton stalk biochar application on soil microflora of continuous cotton cropping under use of antagonistic actinomycetes. Chinese Journal of Eco-Agriculture 25(3):400-409. https://doi.org/10.13930/j.cnki.cjea.160583

Ma ZX, Yang LY, Yan HX, Kennedy JF, Meng XH (2013) Chitosan and oligochitosan enhance the resistance of peach fruit to brown rot. Carbohyd Polym 94(1): 272-277. https://doi.org/10.1016/j. carbpol.2013.01.012

Mazzola M, Strauss SL (2012) Replant disease control and soil system resilience to pathogen infestation in response to Brassicaceae seed meal amendment. Phytopathology 102:S4-S4

Meng L, Wang L (2009) Overview of the antibacterial effect of chitosan on multiple plant pathogen. Pesticide 48(11):781-783. https://doi.org/10.16820/j.cnki.1006-0413.2009.11.001

Meng PP, Liu X, Qiu HZ, Qiu HZ, Zhang WM, Zhang CH, Wang D, Zhang JL, Shen QR (2012) Fungal population structure and its biological effect in rhizosphere soil of continuously cropped potato. Chin $\mathrm{J}$ Appl Ecol 23(11):3079-3086. https://doi.org/10.1111/j.1949-8594.1906.tb02960.x

Meng XH, Yang LY, Kennedy JF, Tian SP (2010) Effects of chitosan and oligochitosan on growth of two fungal pathogens and physiological properties in pear fruit. Carbohydrate Polymers 81(1): 70-75. https://doi.org/10.1016/j. carbpol. 2010.01.057

Niu B, Paulson JN, Zheng XQ, Roberto K (2017) Simplified and representative bacterial community of maize roots. Proc Natl Acad Sci USA 112(12):E2450-E2459. https://doi.org/10.1073/pnas.1616148114

Niu QY, Han YS, Xu LX, Zhang AY, Yi HL, Guo EH (2018) Effects of crop rotation on the physicochemical properties of cornfield soil and the bacterial community in the rhizosphere soil of millet. Journal of AgroEnvironment Science 37(12):2802-2809. https:// doi.org/10.11654/jaes.2018-0128

Olanrewaju OS, Ayangbenro AS, Glick BR, Babalola OO (2019) Plant health: feedback effect of root exudates -rhizobiome interactions. Appl Microbiol Biotechnol 103(3):1155-1166. https://doi.org/10.1007/s00253-018-9556-6

Qin S, Yeboah S, Li C, Qin SH, Yeboah S, Cao L, Zhang JL, Shi SL, Liu YH (2017) Breaking continuous potato cropping with legumes improves soil microbial communities, enzyme activities and tuber yield. PLoS One 12(5):e0175934. https://doi.org/10.1371/journal.pone.0175934 
Sun F, Tian W, Zhang F, Chen Y, Ren XM, Pang FH, Li YY, Yao LG, Chen ZJ (2019) Composition and predictive functional analysis of rhizosphere bacterial communities in riparian buffer strips in the Danjiangkou reservoir, China. Environmental Science 40(1):421-429.

https://doi.org/10.13227/j.hjkx.201805086

Sun XZ, Liu JG (2019) Allelopathic effects of onion and cumin on cotton growth and soil phenolics content. Allelopathy Journal 47(1):137-148. https://doi.org/10.26651/allelo.j/2019-47-1-1227

Sun X, Lin YL, Li BL, Huang LF (2020) Analysis and function prediction of soil microbial communities of Cynomorium songaricum in two daodi-origins. Acta Pharmaceutica Sinica 55(6):1334-1344.

https://doi.org/10.16438/j.0513-4870.2019-1034

Tan Y, Cui YS, Li HY, Kuang AX, Li XR, Wei YL, Ji XL (2016) Rhizospheric soil and root endogenous fungal diversity and composition in response to continuous Panax notoginseng cropping practices. Microbiol Res 194:10-19. https://doi.org/10.1016/j.micres.2016.09.009

Vaara M (1992) Agents that increase the permeability of the outermembrane. Microbiol Rev 56(3):395411. https://doi.org/10.1016/0882-4010(92)90025-J

Wang YF, Fu FY, Li JJ, Wang S, Zhan J, Wu MM, Zhang GJ, Shen X, Chen XS, Mao ZQ (2016) Effects of chitin on the growth of Malus hupehensis Rehd.seedlings and soil environment under replant condition. Acta Ecol Sin 36(19):6218-6225. https://doi.org/10.5846/stxb201501270221

Wen XY, Eric D, Wu Y, Yu R, Chen F (2016) Wheat, maize and sunflower cropping systems selectively influence bacteria community structure and diversity in their and succeeding crop's rhizosphere. Journal of Integrative Agriculture 15(8):1892-1902. https://doi.org/10.1016/S2095-3119(15)61147-9

Wu HM, Qin XJ, Wang JY, Wu LK, Chen J, Fan JK, Zheng L, Tangtai HP, Arafat Y, Lin WW, Luo XM, Lin S, Lin WX (2019) Rhizosphere responses to environmental conditions in Radix pseudostellariae under continuous monoculture regimes. Agr Ecosyst Environ 270-271:19-31.

https://doi.org/10.1016/j.agee.2018.10.014

Xiao XM, Cheng ZH, Meng HW, Khan MA, Li HZ (2012) Intercropping with garlic alleviated continuous cropping obstacle of cucumber in plastic tunnel. Acta Agriculturae Scandinavica 62(8):696-705. https://doi.org/ 10.1080/09064710.2012.697571

Yang P, Zhai YP, Zhao X, Wang SM, Liu HL, Zhang X (2020) Effect of interaction between arbuscular mycorrhizal fungi and rhizobium on Medicago sativa rhizosphere soil bacterial community structure and PICRUSt functional prediction. Microbiology China 47(11):3868-3879.

https://doi.org/10.13344/j.microbiol.china.190978

Yi J, Qiao CZ, Gu HT, Zhu D, Wang MY, Zhang YX, Zhang CR, Yang YJ (2020) Allelochemicals of panax notoginseng and their effects on various plants and rhizosphere microorganisms. Plant Diversity 
Yu GB, Wu FZ, Zhou XG (2011) Effects of rotations of cucumber with wheat and hairy vetch on soil microecological environment and its yield. Acta Pedol Sin 48(1):175-184. CNKI:SUN:TRXB.0. 2011-01-021

Zakrzewska A, Boorsma A, Brul S, Hellingwerf KJ, Klis FM (2005) Transcriptional response of Saccharomyces cerevisiae to the plasmamembrane-perturbing compound chitosan. Eukaryot Cell 4(4):703-715. https://doi.org/10.1128/EC.4.4.703-715.2005

Zhang HL, Bai NL, Zheng XQ, Li SX, Zhang JQ, Zhang HY, Zhou S, Sun HF, Lv WG (2021) Effects of straw returning and fertilization methods on soil bacterial and fungal community structure and diversity in ricewheat rotation. Chinese Journal of Eco-Agriculture 29(3):531-539.

https://doi.org/10.13930/j.cnki.cjea.200502

Zhang HY, He JZ, Xu B, Gong MY, Zhang LL (2010) Variety of soil microbial structure in continuous cropping cotton field in South Xinjiang. Microbiology China 37(5): 689-695.

https://doi.org/13344/j.microbiol.china.2010.05.018

Zhang ZY, Chen H, Yang YH, Chen T, Lin RY, Chen XJ, Lin WX (2010) Effects of continuous cropping on bacterial community diversity in rhizosphere soil of Rehmannia glutinosa. Chin J Appl Ecol 21(11):28432848. https://doi.org/10.3724/SP.J.1142.2010.40491

Zhou YX, Li MQ, Huang ZJ, Hou ZA, Min W (2021) Effects of long-term saline water drip irrigation on physicochemical properties and cotton growth in grey desert soil. Agric Res Arid Areas 39(4):12-20. https://doi.org/10.7606/j.issn.1000-7601.2021.04.02

Zhou X, Yu G, Wu F (2012) Soil phenolics in a continuously mono-cropped cucumber (Cucumis sativus L.) system and their effects on cucumber seedling growth and soil microbial communities. Eur J Soil Sci 63(3):332-340. https://doi.org/10.1111/j.1365-2389.2012.01442.x

Zhuang JH, Yang CC, Tang SG, Wei HL, Gao ZG (2009) The allelopathy of root extracts of several greenhouse vegetables on muskmelon. Seed 28(11):94-96. https://doi.org/10.16590/j.cnki.10014705.2009.11.073

\section{Figures}




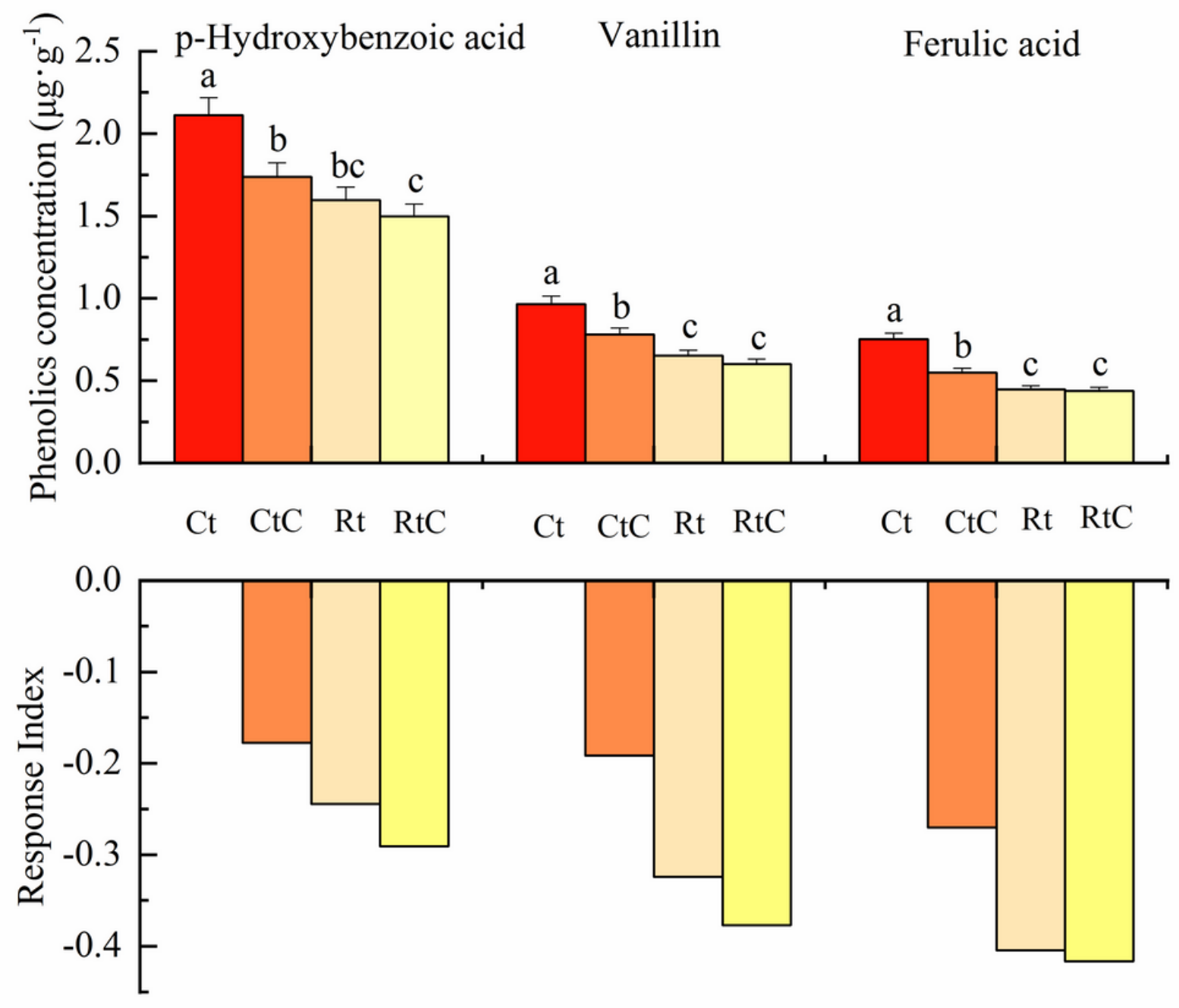

Treatment

Figure 1

Soil phenolic acid content and its response index in different treatments. Ct: cotton continuous crop; CtC: cotton continuous crop with chitosan application; Rt: cotton-corn-wheat rotation; RtC: crop rotation with chitosan application. Positive response index (RI) value indicates that the value is greater than that in the control, while negative value indicates that the value is lower than that in the control. The absolute value of RI value indicates the level of the impact 


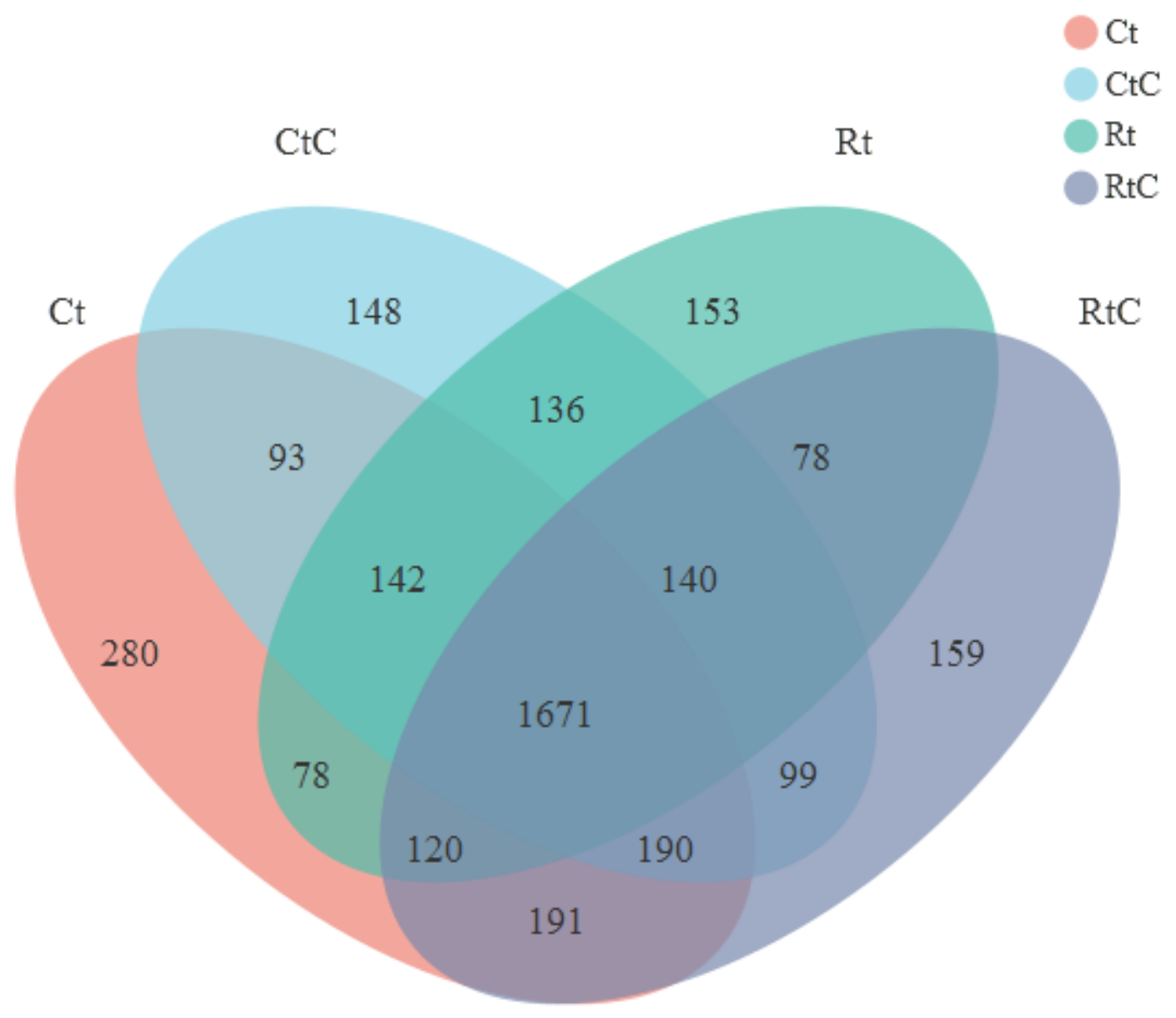

Figure 2

Venn diagram of rhizosphere soil bacteria OTUs in different treatments. Different colors represent different subgroups (or samples). The numbers in the overlapping part represent the number of species shared by multiple subgroups, and the numbers in non-overlapping parts represent the number of species specific to the corresponding subgroup. The figure below shows the bar chart of the total number of species in each subgroup at selected taxonomic levels 
$\mathrm{Ct}$
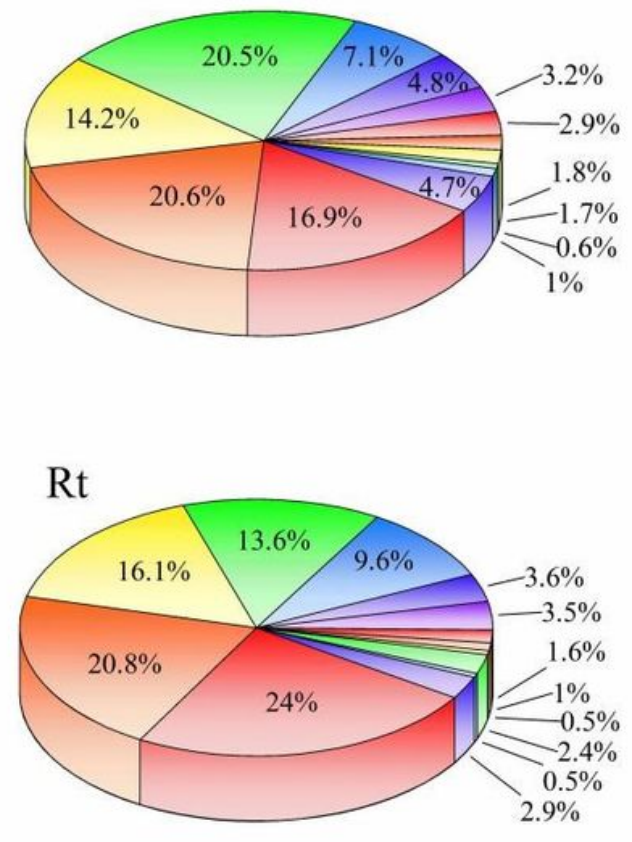

$\mathrm{CtC}$

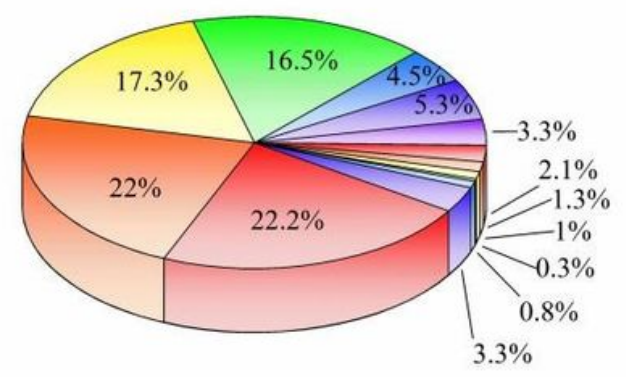

$\mathrm{RtC}$

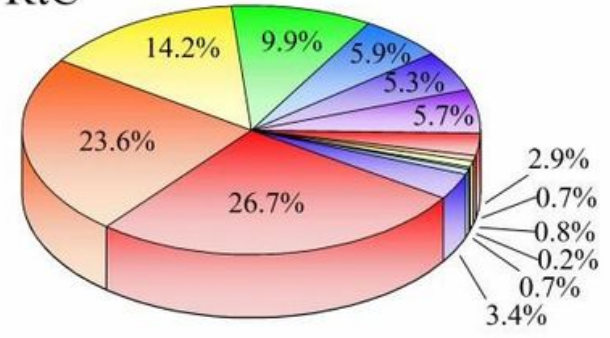

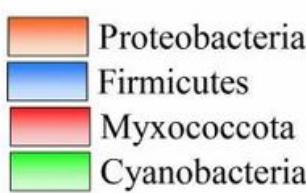

Cyanobacteria

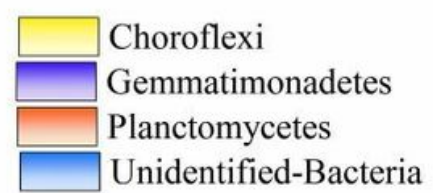

\section{Figure 3}

Composition and abundance of rhizosphere soil bacterial community at phylum level in different treatments 


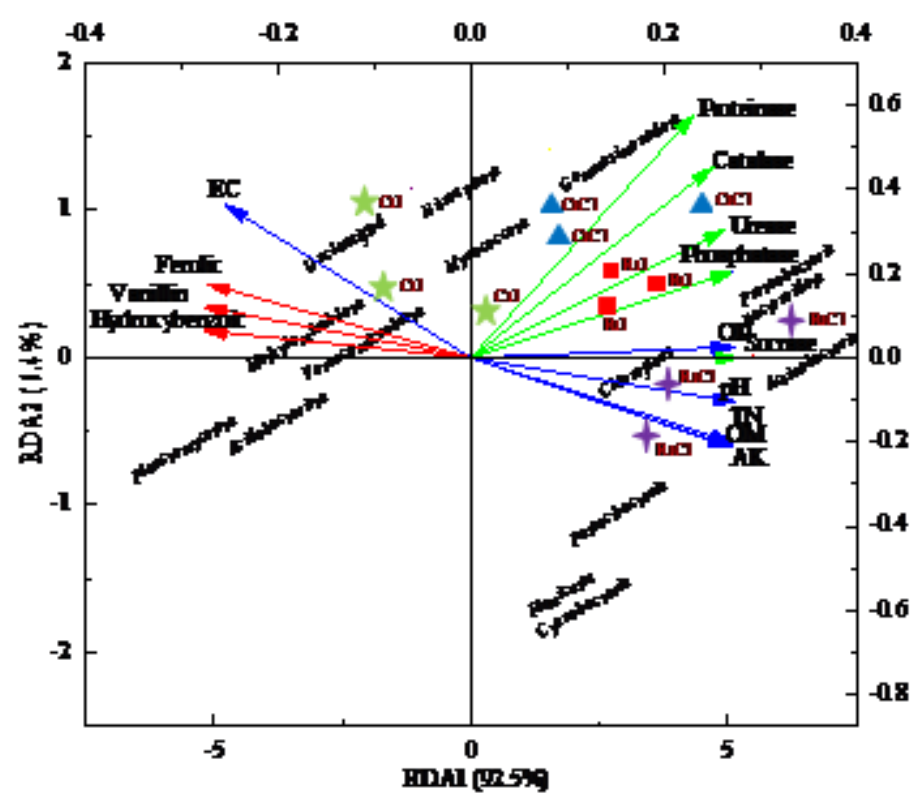

Figure 4

RDA analysis of rhizosphere soil bacteria diversity and environmental factors in different treatments. The purple line represents the nutrient index, the green line represents the enzyme activity, and the red line represents the root exudates. Five-pointed star, triangle, square, and four-pointed star represent $\mathrm{Ct}$, CtC, Rt, and RtC, respectively

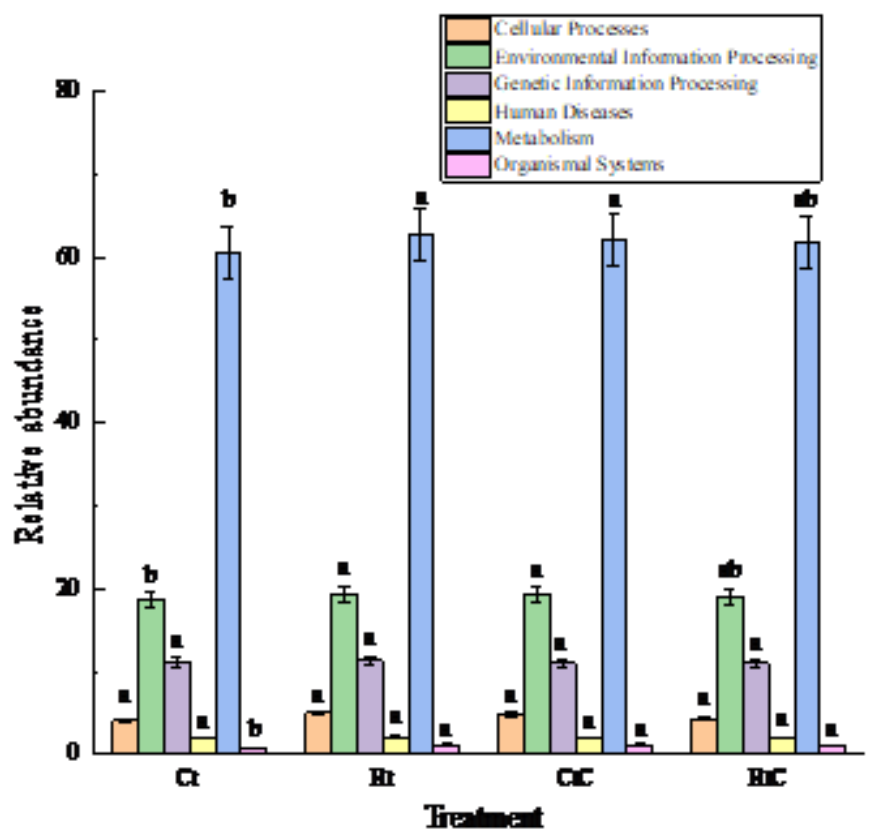

Figure 5 
Abundance of KEGG functional genes of rhizosphere soil bacteria in different treatments (primary functional layer). Different lowercase letters represent significant differences among different treatments $(P<0.05)$

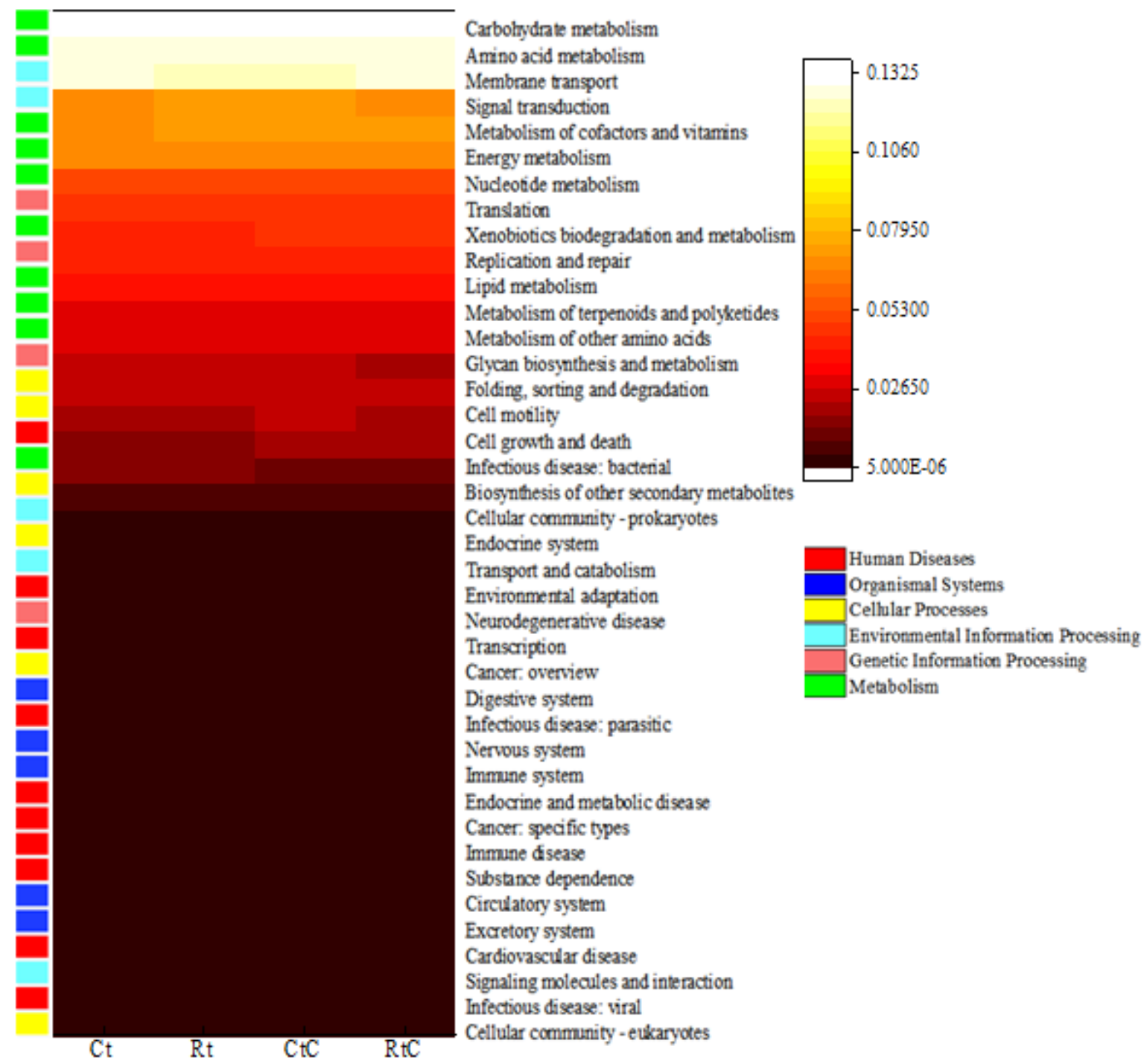

\section{Figure 6}

Heat map of functional diversity of rhizosphere soil bacteria in different treatments 


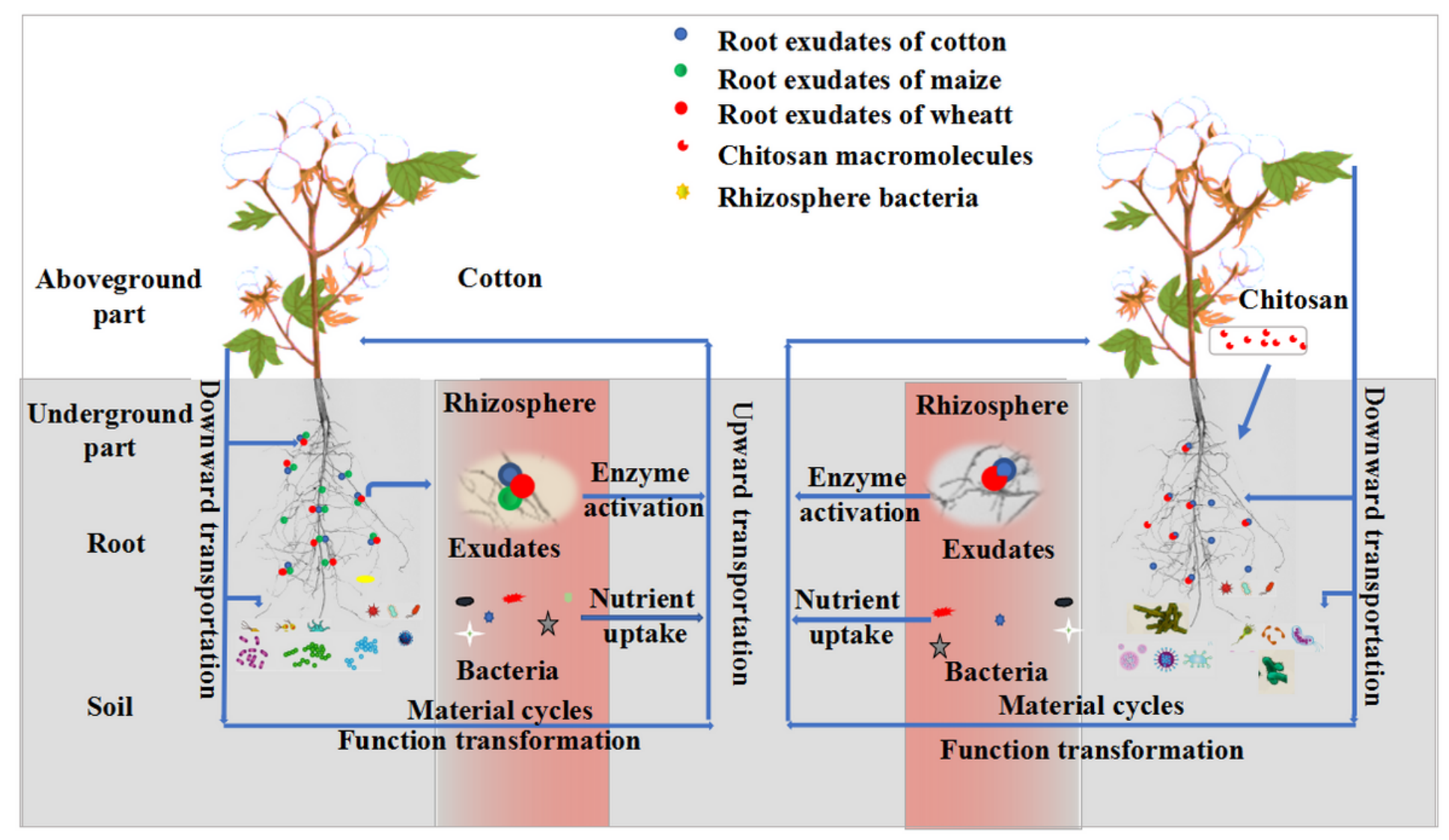

Figure 7

Distribution of root exudates and microbial community under crop rotation (Rt) and continuous cropping with chitosan application treatment (CtC) 